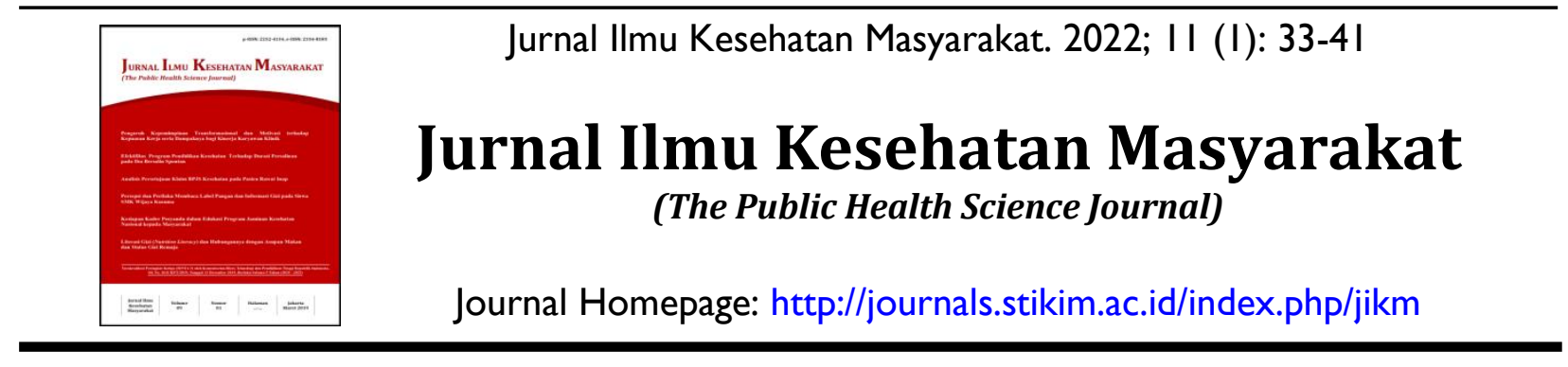

\title{
Analisis Minat Kunjung Ulang Pasien Non BPJS di Unit Rawat Jalan Rumah Sakit "X"
}

\author{
Jesslyn Valentina Jonathan ${ }^{1 *}$, Tantri Yanuar Rahmat Syah ${ }^{2}$, CSP \\ Wekadigunawan ${ }^{3}$ \\ ${ }^{1-3}$ Program Studi S2 Magister Administrasi Rumah Sakit, Universitas Esa Unggul
}

\begin{abstract}
Abstrak
Minat kunjung ulang bagi industri jasa merupakan hal yang sangat penting karena mempertahankan loyalitas konsumen jangka panjang adalah kunci kesuksesan sebuah bisnis, termasuk rumah sakit. Banyak faktor yang mempengaruhi minat kunjung ulang, diantaranya adalah customer perceived value, citra merek, kepercayaan, kepuasan dan sebagainya. Penelitian ini bertujuan untuk menganalisis pengaruh customer perceived value dan citra merek terhadap minat kunjung ulang pasien non BPJS di unit rawat jalan Rumah Sakit " $X$ " dengan kepercayaan pasien sebagai variabel intervening. Desain penelitian yang digunakan adalah penelitian analitik kuantitatif dengan pendekatan kausalitas. Sumber sampel didapat berupa sampel primer. Penulis menggunakan metode survei dengan instrumen kuesioner yang disebarkan kepada 200 orang sampel. Analisis sampel hasil kuisioner dilakukan menggunakan SEM dan diilustrasikan melalui statistik deskriptif. Berdasarkan nilai $T$, hasil penelitian menunjukkan bahwa customer perceived value $(T$ value $=9,93)$ dan citra merek ( $T$ value $=6,04$ ) memiliki pengaruh positif pada kepercayaan pasien, dan customer perceived value ( $T$ value $=2,4 \mathrm{I}$ ) berpengaruh positif terhadap minat kunjung ulang. Namun temuan pada penelitian ini bahwa citra merek $(T$ value $=0,14)$ dan kepercayaann pasien $(T$ value $=I, 22)$ ternyata tidak memiliki pengaruh terhadap minat kunjung ulang pasien non BPJS di unit rawat jalan Rumah Sakit " $X$ ”. Dengan demikian, Rumah Sakit " $X$ ” dapat lebih berfokus kepada variabel lainnya dalam rangka perbaikan di kemudian hari.
\end{abstract}

Kata Kunci: Customer perceived value, citra merek, kepercayaan pasien, minat kunjung ulang pasien.

\begin{abstract}
Revisit intention is very important for service industry because maintaining customer's loyalty for a long term is the key of success for a business including hospital. Many factors affect revisit intention, including: customer perceived value, brand image, patient's trust, patient's satisfaction and so on. The purpose of this study was to determine the effect of customer perceived value and brand image on revisit intention of private (non BPJS) patient in outpastient unit of " $X$ " Hospital, with patient's trust as intervening variable. The research design is quantitative analytic research with a causality approach. The sampel source is obtained in the form of primary sampel The author uses survey method with questionnaires instrument spread to 200 samples. Analysis of result was carried out using SEM and illustrated through descriptive statistics. Based on T value, research findings indicate that customer perceived value and brand image has positive effect on patient's trust, customer perceived value has positive effect on patient's revisit intention. However, brand image and patient's satisfaction has no effect on patient's revisit intention in " $X$ " Hospital. By implication, " $X$ " Hospital has to focus also on another variable for future improvement.
\end{abstract}

Keywords: Customer perceived value, brand image, patient's trust, patient's revisit intention.

Korespondensi*: Jesslyn Valentina Jonathan, Program Studi S2 Magister Administrasi Rumah Sakit, Universitas Esa Unggul, Jl. Arjuna Utara No.9, RT.I/RW.2, Duri Kepa, Kec. Kb. Jeruk, Jakarta Barat I I5 I0, E-mail: jesslyn_val@yahoo.com, No.Telp: $+6287884413699$ 


\section{Pendahuluan}

Minat kunjung ulang merupakan hal yang sangat penting karena kunci kesuksesan dalam sebuah usaha adalah mampu mempertahankan loyalitas konsumen dalam jangka panjang terutama usaha dalam bidang jasa. ${ }^{1}$ Tujuan utama dalam strategi manajemen adalah mencapai loyalitas konsumen, oleh karena itu penting untuk memahami faktor-faktor yang mempengaruhi loyalitas konsumen. ${ }^{2}$ Penyedia layanan yang memiliki pelanggan setia akan mendapatkan banyak manfaat yang signifikan, seperti peningkatan pangsa pasar, pengurangan biaya pemasaran menarik pelanggan baru, meningkatkan pendapatan dan profit. ${ }^{3}$

Penilaian pelanggan secara keseluruhan atas manfaat produk atau jasa, kualitas layanan, harga, nilai emosional dan sosial dari sebuah produk atau jasa berdasarkan persepsi tentang apa yang diterima dan diberikan oleh pelanggan kita kenal dengan customer perceived value. Nilai inilah yang menjadi salah satu kunci dari loyalitas pelanggan yang mempengaruhi keinginan konsumen untuk melakukan pembelian. ${ }^{4}$ Nilai yang dirasakan telah menjadi kriteria penting dalam pengembangan strategi manajerial untuk menciptakan, mengkomunikasikan, dan memberikan nilai tersebut kepada pelanggan. ${ }^{5}$

Salah satu faktor yang dianggap menunjang minat konsumen untuk menggunakan jasa tertentu yaitu citra merek. Ketika sebuah organisasi memiliki citra yang baik, konsumen dapat menyimpulkan bahwa produknya dapat diandalkan dan memiliki kualitas tinggi serta memberikan pengaruh pada mereka untuk melakukan pembelian. Kepercayaan pasien merupakan elemen penting dalam hubungan dokter-pasien. Studi sebelumnya menyebutkan bahwa pada perusahaan yang bergerak di bidang jasa, faktor kepercayaan berkaitan erat dengan keputusan berperilaku.

Hubungan beberapa variabel tersebut telah dianalisa sebelumnya oleh $\mathrm{Wu}$ dan $\mathrm{Li}$ melalui penelitiannya yang menyatakan bahwa nilai pelanggan berpengaruh positif pada minat kunjung ulang. ${ }^{6}$ Juga penelitian yang dilakukan oleh $\mathrm{Wu}$ yang menyebutkan bahwa citra merek RS yang positif dapat meningkatkan loyalitas, yang akhirnya meningkatkan minat kunjung ulang. ${ }^{7}$ Namun demikian, belum ada penelitian sebelumnya yang menggunakan empat variabel customer perceived value, citra merek, kepercayaan dan minat kunjung ulang dalam model yang sama.

Rumah Sakit "X" sebagai tempat melakukan penelitian adalah rumah sakit kelas C yang berdiri sejak tahun 2006. Pangsa pasar Rumah Sakit "X" terbagi menjadi $90 \%$ pasien BPJS dan $10 \%$ pasien umum. Rumah sakit harus menambah jumlah pasien umum, karena diperlukan peningkatan pendapatan bagi RS untuk tetap bertahan dan berkembang. Menurut sampel kunjungan ulang pasien Non BPJS di unit rawat jalan Rumah Sakit " $X$ " selama 3 tahun 2018-2020 didapatkan sampel bahwa jumlah kunjungan pasien lama non BPJS di unit rawat jalan selalu turun. Terjadi penurunan kunjungan pasien lama Non BPJS semester 1 Tahun 2020 sebesar 28,1\% dibanding dengan kunjungan pasien lama Non BPJS semester 2 Tahun 2019. Salah satu kendala yang dihadapi Rumah Sakit "X" dalam upaya meningkatkan jumlah pasien umum adalah masalah citra merek rumah sakit sebagai "rumah sakit kelas menengah ke bawah" menyebabkan sulit meningkatkan daya jual kepada pasien umum yang persepsinya telah banyak dipengaruhi oleh word of mouth dan variasi pengalaman berobat di masa lalu.

Berdasarkan hasil wawancara terhadap beberapa pasien pada unit rawat jalan Rumah Sakit "X", alasan yang menarik minat mereka untuk berobat di RS "X" antara lain karena pelayanannya cukup baik, cocok dengan dokternya, dekat dengan tempat tinggal, harga yang relatif terjangkau dan pendaftaran yang teratur. Tetapi masih terdapat keluhan terkait 
kecepatan pelayanan dan responsivitas petugas. Namun belum pernah menilai aspek kepercayaan di rumah sakit ini. Penelitian ini bertujuan agar rumah sakit dapat mengetahui pengaruh citra merek, customer perceived value dan kepercayaan pasien terhadap minat kunjung ulang agar rumah sakit dapat mengubah persepsi masyarakat, meningkatkan citra, dan memberikan pengalaman yang menyenangkan ketika berobat serta kepercayaan bagi pasien, sehingga minat kunjung ulang, volume dan value RS " $X$ " akan meningkat. Berdasarkan latar belakang diatas, maka penelitian ini bertujuan untuk mengalisis minat kunjung ulang pasien non BPJS di unit rawat jalan Rumah Sakit "X".

\section{Metode}

Penelitian ini termasuk jenis eksplanatori, menggunakan pendekatan kuantitatif dan berdasarkan tingkat eksplanasinya digolongkan dalam penelitian asosiatif. Populasi dalam penelitian ini adalah pasien umum (nonBPJS) di unit rawat jalan Rumah Sakit "X". Sampel pada penelitian ini adalah sejumlah pasien umum (non-BPJS) di poliklinik yang sudah pernah berobat di unit rawat jalan Rumah Sakit " $X$ " sebelumnya minimal $1 \mathrm{x}$ dalam 2 tahun terakhir dan melakukan kunjungan pada bulan Januari-Juni 2020. Pengambilan sampel menggunakan metode non probability sampling, yaitu purposive sampling dan didapatkan sebanyak 200 sampel. Sampel didapatkan di Rumah Sakit " $X$ " pada periode Oktober hingga November 2020. Sampel dikumpulkan sebanyak 220 dan hanya 200 sampel yang lengkap. 200 sampel yang dapat digunakan masih diatas jumlah minimum yaitu 180 sampel.

Variabel yang yang diteliti dalam penelitian ini yaitu minat kunjung (indikator: minat referensial, minat preferensial dan minat kunjung ulang), customer perceived value (indicator: effort, time dan money), citra merek (indicator: keunggulan asosiasi merek, kekuatan asosiasi merek dan keunikan asosiasi merek) dan kepercayaan (indikator: kepercayaan atribut objek, kepercayaan mafaat atribut dan kepercayaan manfaat objek).

Pembuktian hipotesa dilakukan dengan metode survey yang mengambil sampel untuk diteliti dan menggunakan instrumen berbentuk kuisioner dengan menggunakan skala likert yang memiliki 5 pilihan jawaban, yaitu sangat tidak setuju, tidak setuju, ragu - ragu, setuju, dan sangat setuju. Analisa data dilakukan dengan metode analisis jalur (path analysis) untuk mengetahui pengaruh customer perceived value dan citra merek terhadap minat kunjung ulang dengan kepercayaan pasien sebagai variabel mediasi. Pengujian terhadap model penelitian dilakukan dengan menggunakan Structural Equation Modelling (SEM). Jika nilai $\mathrm{T} \geq 1,96$ maka hipotesis diterima dan jika nilai $\mathrm{T}<1,96$ maka hipotesis ditolak.

\section{Hasil}

Sebagian besar responden berdomisili di Bekasi Barat (46\%), berjenis kelamin wanita (59\%), berusia 41-50 tahun (45\%), tingkat pendidikan terakhir D3/S1/ sederajatnya (67\%), bekerja sebagai pegawai swasta (66\%), pengeluaran berobat per bulan sebesar Rp.200.000500.000 (46\%), berkunjung $>2 \times(80 \%)$ dan berobat di Rumah Sakit "X" karena faktor pelayanannya baik (43\%).

\section{Confirmatory Factor Analysis (CFA)}

Confirmatory Factor Analysis (CFA) digunakan untuk memeriksa lebih lanjut validitas item yang mengukur semua konstruk dalam penelitian ini. CFA digunakan untuk mendapatkan model fit untuk model pengukuran dan untuk menguji validitas konvergen dan diskriminan dari konstruk dalam penelitian. Kriteria model yang dianggap fit meliputi: (1) Normed Chi-square ( $\chi^{2} /$ df) kurang dari 3, (2) Root Mean Square Error of Approximation (RMSEA) kurang 
dari 0,08, (3) Expected Cross Validation Index (ECVI) model sedikit lebih kecil dari ECVI saturated model dan selisihnya jauh lebih besar lagi dari ECVI independence model (4) Akaike Information Criterion (AIC) dan Consistent Akaike Information Creterion (CAIC) model sedikit lebih kecil dari AIC dan CAIC saturated model dan selisihnya jauh lebih besar lagi dari AIC dan CAIC independence model (5) Fit Index melebihi 0,90 (6) Critical $N$ lebih dari 200 (7) Goodness of fit (GFI) lebih besar sama dengan 0,90 .

Hasil CFA menunjukkan bahwa $\chi 2$ / $\mathrm{df}=1.911 ;$ RMSEA $=0.068 ;$ ECVI model $=1.67$, ECVI saturated $=1,72$, ECVI Independence $=28.09 ;$ AIC model $=$ 332.44, AIC saturated $=342.00$, AIC
Independence $=28.09$, CAIC model $=$ 607.53, CAIC saturated $=1077.01$, CAIC independence $=5666.59 ; \mathrm{PNFI}=0,67$; Critical $\mathrm{N}=131.61 ; \mathrm{GFI}=0.90$. Hasil ini menunjukkan bahwa model pengukuran cukup fit.

Hasil CFA menunjukkan bahwa nilai loading factor untuk 18 pernyataan $>0,40$ sehingga dapat dikatakan bahwa 18 pernyataan ini valid. Selanjutnya, untuk konstruksi memenuhi persyaratan dengan nilai pembebanan faktor berkisar antara 0,57 hingga 0,95 (Tabel 3). Nilai AVE untuk masing-masing konstruk melebihi titik potong 0,50 dan memiliki reliabilitas komposit lebih dari 0,70 (Tabel 3). Hal ini menunjukkan bahwa validitas konvergen sampel telah ditetapkan.

Tabel 1. Distribusi Karakteristik Responden

\begin{tabular}{|c|c|c|c|}
\hline Karakteristik & Kategori & $\mathbf{n}$ & $\%$ \\
\hline \multirow[t]{4}{*}{ Domisili } & Bekasi Utara & 5 & 2,5 \\
\hline & Domisili Lainnya & 43 & 21,5 \\
\hline & Bekasi Selatan & 60 & 30 \\
\hline & Bekasi Barat & 92 & 46 \\
\hline \multirow[t]{2}{*}{ Jenis Kelamin } & Laki-Laki & 83 & 41,5 \\
\hline & Perempuan & 117 & 58,5 \\
\hline \multirow[t]{5}{*}{ Usia } & $<20$ tahun & 6 & 3 \\
\hline & $20-30$ tahun & 24 & 12 \\
\hline & $31-40$ tahun & 57 & 28,5 \\
\hline & $41-50$ tahun & 90 & 45 \\
\hline & $>50$ tahun & 23 & 11,5 \\
\hline Pendidikan & SD & 13 & 6,5 \\
\hline \multirow[t]{4}{*}{ Terakhir } & SMP & 3 & 1,5 \\
\hline & SMA & 24 & 12 \\
\hline & D3/S1 atau sederajatnya & 134 & 67 \\
\hline & Lain - Lain & 26 & 13 \\
\hline \multirow[t]{6}{*}{ Pekerjaan } & Pelajar & 16 & 8 \\
\hline & Pegawai negeri & 4 & 2 \\
\hline & Pedagang & 2 & 1 \\
\hline & Pegawai Swasta & 133 & 66,5 \\
\hline & Wiraswasta & 30 & 15 \\
\hline & Pekerja Lainnya & 15 & 7,5 \\
\hline Pengeluaran & $<$ Rp. 100.000,- & 10 & 5 \\
\hline \multirow[t]{3}{*}{ Berobat per Bulan } & Rp.100.000 - Rp. 199.000 & 18 & 9 \\
\hline & Rp. 200.000 - Rp. 500.000 & 93 & 46,5 \\
\hline & $>$ Rp. .500 .000 & 79 & 39,5 \\
\hline \multirow[t]{2}{*}{ Jumlah Kunjungan } & $2 \mathrm{x}$ & 41 & 20,5 \\
\hline & $>2 \mathrm{x}$ & 159 & 79,5 \\
\hline \multirow[t]{5}{*}{ Alasan Berobat } & Harga kompetitif & 5 & 2,5 \\
\hline & Cocok dengan dokternya & 35 & 17,5 \\
\hline & Pelayanannya baik & 85 & 42,5 \\
\hline & Lokasi dekat & 65 & 32,5 \\
\hline & Gabungan & 10 & 5 \\
\hline
\end{tabular}


Tabel 2. Hasil Uji Kecocokan Model (GOF)

\begin{tabular}{|c|c|c|c|}
\hline Group & Indicator & Value & Keterangan \\
\hline \multirow[t]{4}{*}{1} & Degree of Freedom & 107 & \multirow{4}{*}{ Good Fit } \\
\hline & Chi Square & 204,44 & \\
\hline & $\mathrm{NCP}$ & 107 & \\
\hline & Confidence Interval & $60.88 ; 141.82$ & \\
\hline \multirow[t]{2}{*}{2} & RMSEA & 0,068 & \multirow[b]{2}{*}{ Good Fit } \\
\hline & $\begin{array}{l}\text { Confidence Interval } \\
\text { P Value }\end{array}$ & $\begin{array}{c}0,053 ; 0,082 \\
0,022\end{array}$ & \\
\hline \multirow[t]{4}{*}{3} & ECVI Model & 1,67 & \multirow{4}{*}{ Good Fit } \\
\hline & ECVI Saturated & 1,72 & \\
\hline & ECVI Independence & 28,09 & \\
\hline & Confidence Interval & 1,$49 ; 1,89$ & \\
\hline \multirow[t]{6}{*}{4} & AIC Model & 332,44 & \multirow{6}{*}{ Good Fit } \\
\hline & AIC Saturated & 342,00 & \\
\hline & AIC Independence & 5589,22 & \\
\hline & CAIC Model & 607,53 & \\
\hline & CAIC Saturated & 1077,01 & \\
\hline & CAIC Independence & 5666,59 & \\
\hline \multirow[t]{6}{*}{5} & NFI & 0,96 & \\
\hline & CFI & 0,98 & \multirow{5}{*}{ Good Fit } \\
\hline & NNFI & 0,97 & \\
\hline & IFI & 0,98 & \\
\hline & RFI & 0,94 & \\
\hline & PNFI & 0,67 & \\
\hline 6 & Critical N & 131,61 & Marginal Fit \\
\hline \multirow[t]{4}{*}{7} & Standarized RMR & 0,056 & \multirow{4}{*}{ Marginal Fit } \\
\hline & GFI & 0,90 & \\
\hline & AGFI & 0,84 & \\
\hline & PGFI & 0,056 & \\
\hline
\end{tabular}

Tabel 3. Confirmatory Factor Analysis

\begin{tabular}{lcccc}
\hline \multicolumn{1}{c}{ Variabel } & Jumlah & $\begin{array}{c}\text { Loading Factor } \\
(>\mathbf{0 , 4 0})\end{array}$ & $\begin{array}{c}\text { CR } \\
(>\mathbf{0 , 7 0 )}\end{array}$ & $\begin{array}{c}\text { AVE } \\
(>\mathbf{0 , 5 0})\end{array}$ \\
\hline Customer perceived value & 4 & $0,57-0,95$ & 0,81 & 0,52 \\
Citra Merek & 7 & $0,65-0,95$ & 0,93 & 0,68 \\
Kepercayaan & 4 & $0,73-0,85$ & 0,87 & 0,65 \\
Minat Kunjung Ulang & 3 & $0,64-0,84$ & 0,80 & 0,53 \\
\hline
\end{tabular}

\section{Pengujian Model Struktural dan Hipotesis}

Perangkat lunak statistik (LISREL) digunakan untuk menguji model struktural penelitian ini. Hasil dari jalur kausal disajikan pada gambar 1 dan tabel 4 . Ditemukan bahwa tiga hipotesis dalam penelitian ini ditemukan signifikan yaitu $\mathrm{H} 1, \mathrm{H} 2$ dan $\mathrm{H} 4$ Sedangkan dua hipotesis tidak berpengaruh yaitu $\mathrm{H} 3$ dan $\mathrm{H} 5$. Menurut jalur kausal pada Tabel 3, customer perceived value $(\mathrm{T}$ value $=9,93)$ dan citra merek ditemukan memiliki pengaruh yang signifikan terhadap kepercayaan. Selain itu, customer perceived value $(\mathrm{T}$ value $=2,41)$ ditemukan memiliki pengaruh yang signifikan terhadap minat kunjung ulang. 


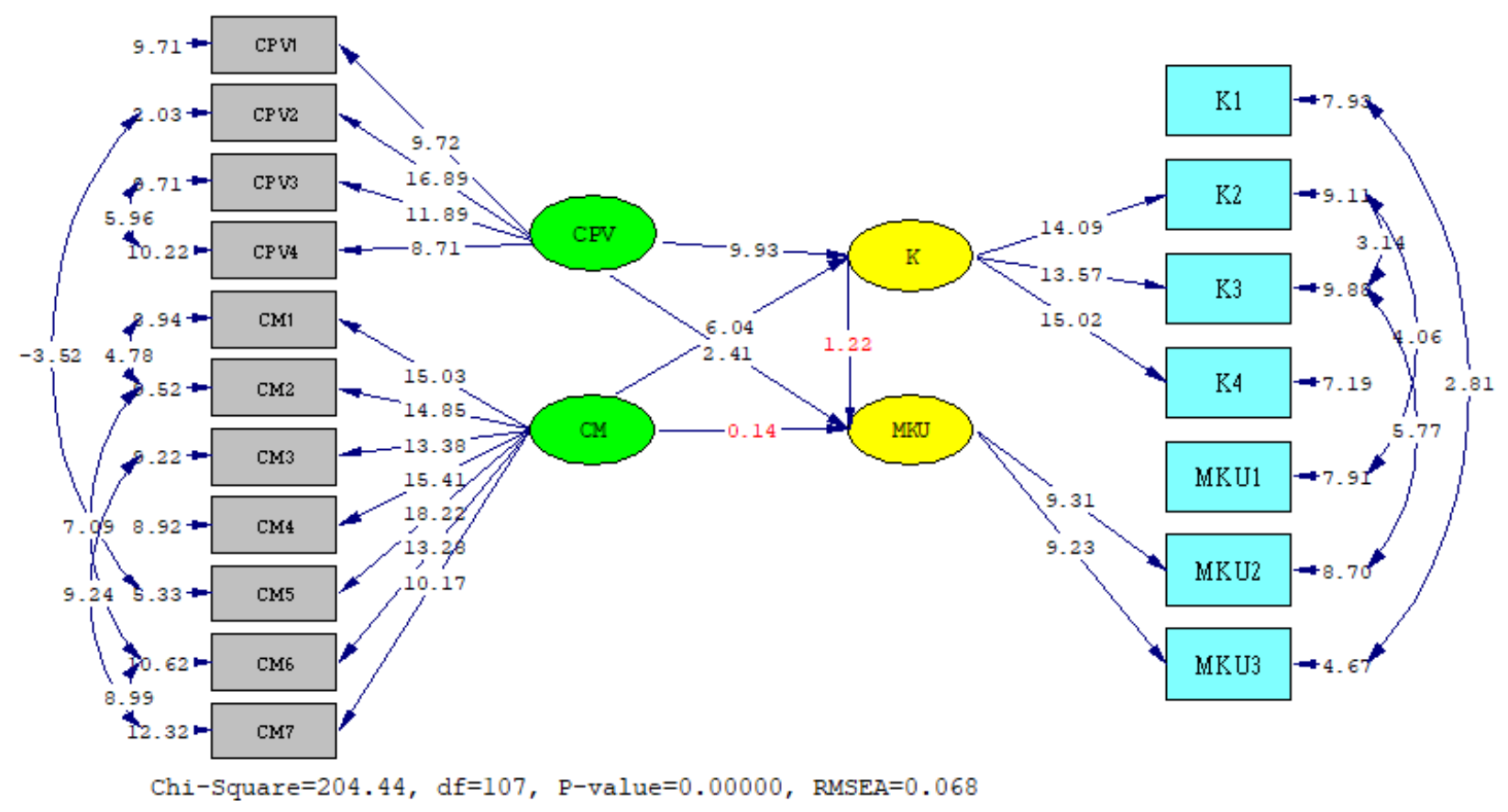

Keterangan : CPV=Customer Perceived Value, $\mathrm{CM}=$ Citra Merek), $\mathrm{K}=$ Kepercayaan, $\mathrm{MKU}=\mathrm{Minat}$ Kunjunga Ulang

Gambar 1. Model Struktural SEM

Tabel 4. Hasil Pengujian Hipotesis

\begin{tabular}{|c|c|c|c|}
\hline Hipotesis & $\begin{array}{c}\text { Pengaruh } \\
\end{array}$ & T Value & Ket. \\
\hline H1 & $\begin{array}{l}\text { Customer perceived value } \rightarrow \\
\text { Kepercayaan Pasien. }\end{array}$ & 9,93 & Diterima \\
\hline $\mathrm{H} 2$ & Citra Merek $\rightarrow$ Kepercayaan Pasien & 6,04 & Diterima \\
\hline $\mathrm{H} 3$ & $\begin{array}{l}\text { Kepercayaan Pasien } \rightarrow \text { Minat } \\
\text { Kunjung Ulang }\end{array}$ & 1,22 & Ditolak \\
\hline $\mathrm{H} 4$ & $\begin{array}{l}\text { Customer perceived value } \rightarrow \text { Minat } \\
\text { Kunjung Ulang }\end{array}$ & 2,41 & Diterima \\
\hline H5 & $\begin{array}{l}\text { Citra Merek } \rightarrow \text { Minat Kunjung } \\
\text { Ulang }\end{array}$ & 0,14 & Ditolak \\
\hline
\end{tabular}

\section{Pembahasan}

Kotler dan Keller mendefinisikan customer perceived value sebagai perbedaan evaluasi konsumen mengenai seluruh manfaat yang didapat dan biaya yang dikeluarkan atas penawaran suatu produk dan persepsi atas alternatifnya. ${ }^{5}$ Customer perceived value dapat digunakan sebagai salah satu cara untuk meningkatkan kepercayaan pasien. Semakin baik customer perceived value yang ditunjukkan dengan adanya kualitas pelayanan yang baik, harga yang kompetitif dan sistem administrasi yang mudah. Hal ini akan meningkatkan kepercayaan pasien terhadap rumah sakit. Hal ini sejalan dengan Peppers dan Rogers yang menyatakan bahwan salah satu faktor yang memberikan kontribusi bagi terbentuknya kepercayaan yaitu persepsi nilai. ${ }^{8}$ Menurut You-Yu Dai dan Chun, kepercayaan pelanggan didorong oleh nilai yang dirasakan pelanggan. ${ }^{9}$ Persepsi nilai tinggi tersebut akan meningkatkan kepercayaan konsumen pada perusahaan.

Kotler dan Amstrong mendefinisikan citra merek sebagai sekumpulan keyakinan yang dianut tentang merek tertentu. Citra merek memiliki pengaruh positif terhadap kepercayaan pasien. ${ }^{10}$ Artinya citra merek 
Rumah Sakit "X" yang baik dan sudah lama dikenal oleh pasien akan mempengaruhi tingkat kepercayaan mereka. Terdapat tiga faktor utama yang membentuk kepercayaan yaitu karakteristik merek (reputasi merek, sifat predictable merek dan kompetensi merek), karakteristik perusahaan (kepercayaan terhadap perusahaan, reputasi perusahan, motif perusahaan yang dirasakan oleh konsumen dan integritas perusahaan) dan karakteristik hubungan merek dengan konsumen (kesesuaian antara konsep diri konsumen dengan kepribadian sebuah merek, kepuasan menggunakan merek, kesukaan terhadap merek, pengalaman menggunakan merek dan pengaruh teman atau lingkungan sosial terhadap pemilihan merek). ${ }^{8}$ hal ini juga sesuai dengan hasil penelitian yang diilakukan oleh Abdullah Alhaddad, yang menggunakan 500 sampel menunjukkan bahwa citra merek mempengaruhi kepercayaan orang terhadap merek tersebut. ${ }^{11}$

Kepercayaan adalah semua pengetahuan yang dimiliki oleh pelanggan dan semua kesimpulan yang dibuat tentang objek, atribut dan manfaatnya. ${ }^{12}$ Walaupun pasien non BPJS percaya dengan Rumah Sakit "X", ada hal lain yang mempengaruhi pasien sehingga mereka tidak ada minat kunjung ulang ke rumah sakit tersebut. Berdasarkan hasil penelitian ini, pasien non BPJS percaya dengan Rumah Sakit "X", namun tidak berpengaruh terhadap minat kunjung ulang mereka pada periode semester 1 tahun 2020. Diduga ada faktor lain sebagai penentu minat kunjung antara lain yaitu keamanan dan persepsi risiko. Perlu diperhatikan diantaranya sistem antrian dan sistem pendaftaran. Rumah sakit masih menggunakan sistem antrian offline, sehingga pasien dapat melakukan reservasi, namun hanya dapat ambil nomor antrian pada saat pasien tersebut sampai di rumah sakit. Sistem pendaftaran BPJS dan non BPJS masih menjadi satu, sehingga membutuhkan waktu yang cukup lama untuk melakukan pendaftaran. Kedua hal ini membuat pasien membutuhkan waktu yang lebih lama pada saat kunjungan. Hal ini sejalan dengan penelitian yang dilakukan oleh Salmi Mohd Isa, Grace Sze Sze Lim dan Phaik Nie terhadap 240 responden bahwa kepercayaan tidak mempengaruhi minat kunjung ulang pasien. ${ }^{13}$ Adapun penelitian lain yang sejalan dengan penelitian ini, yaitu penelitian yang di lakukan oleh Hung-Che Wu, Tao Li dan Meng-Yu Li terhadap 452 responden. ${ }^{6}$

Customer perceived value memainkan peranan penting dalam mempengaruhi minat kunjung ulang. Apabila pasien memiliki persepsi bahwa manfaat yang didapat ketika berobat di unit rawat jalan Rumah Sakit "X" lebih besar dibandingkan biaya yang dikeluarkan, maka minat kunjung ulang pasien akan meningkat. Temuan tersebut sejalan dengan penelitian Dahl dan Umberson, persepsi nilai secara langsung mempengaruhi minat kunjung ulang pelanggan. ${ }^{14,15}$

Walaupun citra merek Rumah Sakit "X" sudah baik dan cukup lama dikenal oleh responden, ada hal lain yang mempengaruhi pasien sehingga mereka tidak ada minat kunjung ulang ke rumah sakit tersebut. Dari hasil penelitian ini diketahui bahwa motivasi pasien dalam memutuskan kunjungan ulang ke Rumah Sakit "X" antara lain faktor kecocokan dengan dokter, harga, dan lokasi, bukan reputasi maupun faktor cakupan pelayanan. Sehingga pasien tidak terlalu mempertimbangkan citra merek, selama kebutuhannya akan hal-hal mendasar yang mendukung pengobatannya terpenuhi. Hipotesis ini sesuai dengan penelitian yang dilakukan oleh Chueh-Shih Lin. ${ }^{16}$ Penelitian tersebut menyebutkan bahwa citra merek tidak memiliki hubungan yang signifikan terhadap minat kunjung ulang. Penelitian Salmi Mohd Isa, Grace Sze Sze Lim dan Phaik Nie juga menyebutkan bahwa citra merek tidak berpengaruh terhadap minat kunjung ulang. ${ }^{13}$ Penelitian lain yang sama hasilnya bahwa citra merek 
tidak berpengaruh terhadap minat kunjung ulang adalah penelitian yang dilakukan oleh Surya Bintarti dan Ergo N.K. ${ }^{17}$ Kemungkinan hal lain itu adalah adanya pandemi Covid-19. Rumah Sakit "X" menerima pasien suspek COVID-19 dan perawatan pasien COVID-19. Oleh karena itu, diduga ada kewaspadaan dari masyarakat untuk berobat ke Rumah Sakit "X" di saat pandemi sekarang ini. Kemungkinan kedua adalah banyaknya warga Bekasi (sekitar 1500an warga dikutip dari kompas, periode Maret hingga September 2020) yang terkena pemutusan hubungan kerja (PHK) dampak dari pandemi COVID-19. Mayoritas responden adalah pegawai swasta, kemungkinan banyak perusahaan swasta yang melakukan pemotongan hak karyawan. Diduga ini akan mempengaruhi kunjungan berobat ke rumah sakit selama periode semester 1 tahun 2020. Sama halnya seperti kepercayaan pasien, kedua hal di atas dapat menyebabkan walaupun Rumah Sakit "X" memiliki citra yang baik di mata pasien, namun belum tentu memiliki minat kunjung berobat kembali ke rumah sakit tersebut pada periode semester 1 tahun 2020.

\section{Kesimpulan}

Berdasarkan hasil penelitian dapat disimpulkan bahwa terdapat pengaruh citra merek terhadap kepercayaan dan customer perceived value terhadap kepercayaan dan minat kunjung ulang. RS " $X$ " dapat meningkatkan minat kunjung ulang dengan lebih fokus dalam pemberian service excellent secara lebih terarah dan melihat perkembangan rumah sakit kompetitor di sekelilingnya. Hal ini dapat diaplikasikan dengan cara buat sistem antrian online sehingga mengurangi lamanya waktu tunggu pasien di rumah sakit, membuat sistem pendaftaran yang berbeda antara BPJS dan non BPJS, menyediakan pelayanan telemedicine dan pelayanan drive thru seperti PCR, dimana walaupun rumah sakit menerima pasien COVID-19 namun semua protokol kesehatan sudah dijalankan dengan baik sehingga kekhawatiran pasien untuk berobat berkurang. Hal ini dapat dilakukan dengan memberikan informasi mengenai protokol kesehatan yang diterapkan di RS " $X$ " melalui media seperti website, instagram atau facebook. Pada penelitian selanjutnya dapat diidentifikasi pasien datang untuk kontrol atau bukan, penelitian juga dapat dilakukan pada beberapa rumah sakit dan tambahkan variabel lain seperti kualitas pelayanan, hubungan marketing, norma subjektif atau word of mouth.

\section{Daftar Pustaka}

1. Chen dan Cheng. Understanding consumer intention in online shopping: a respecification and validation of the DeLone and McLean model. Behav Inf Technology. 2009;28(4): 335-45.

2. Balaji M. Investing in customer loyalty: the moderating role of relational characteristics. Service Business. 2015;9:17-40.

3. Chang CW, Tseng TH dan Woodside AG. Configural algorithms of patient satisfaction, participation in diagnostics, and treatment decisions' influences on hospital loyalty. Journal of Services Marketing. 2013;27(2):91103.

4. Moliner, Sánchez, dan Rodríguez. Perceived relationship quality an post-purchase perceived value: An integrative framework. European journal of marketing. 2007;41(11):1392-422.

5. Kotler P. dan Keller KL. Marketing management $\left(15^{\text {th }}\right.$ ed.). New Jersey: Pearson Education Hall, Inc.;2016.

6. Wu HC, Li T dan Li MY. A study of behavioral intentions, patient satisfaction, perceived value, patient trust and experiential quality for medical. tourists. journal of quality assurance in hospitality \& tourism. 2016;17(2):114-50.

7. Wu CC. The impact of hospital brand image on service quality, patient satisfaction and loyalty. African journal of business management. 2011;5(12):4873-82.

8. Peppers D dan Rogers M. Managing customer relationship. Canada: Willey;2004.

9. Dai YY dan Wang C. Interaction of wechat friends circle and perceived value on consumer trust. Association for computing machinery;2018.

10. Kotler $\mathrm{P}$ dan Amstrong G. Principles of marketing (12 ${ }^{\text {th }}$ ed.). Indonesia: Erlangga;2014.

11. Alhaddad AA. Perceived quality, brand image and brand trust as determinants of brand loyalty. Journal of research in business and 
management. 2015;3(4):1-8.

12. Mowen J. dan Minor M. Perilaku konsumen ( $5^{\text {th }}$ ed.). Indonesia: Erlangga;2002.

13. Isa, S. M., Lim, G. S. Dan Chin, P. N. (2018). Patients' intent to revisit with trust as the mediating role: lessons from Penang Malaysia. International journal of pharmaceutical and healthcare marketing. 2018;13(2):140-59.

14. Dahl D. Social influence and consumer behavior. Journal of customer research. 2013;40(2);iii-v.

15. Umberson D Crosnoe R dan Reczek C. Social relationships and health behavior across the life course. annual review of sociology. 2010;36:139-57.
16. Lin CS. Effect of involvement, flow experience, brand image, atmospherics, and experiential value on visitors' revisit intentions - a case study of a cultural and creative park in kaohsiung city. European journal of scientific research. 2020;156(2):218-34.

17. Bintarti S dan Kurniawan E. A study of revisit intention: experiential quality and image of muara beting tourism site in bekasi district. a study of revisit intention: experiential quality and image of muara beting tourism site in Bekasi district. 2017;20(2a):521-37. 